\title{
BIRDS
}

\section{MOBBING OF GREAT GRAY OWLS AT THE NEST}

SPENCER G. SEALY, Department of Biological Sciences, University of Manitoba, Winnipeg, MB R3T 2N2

\section{Introduction}

Observations abound of animals approaching predators when they initially encounter them, in what seems at first to be a paradoxical strategy. The animals eventually retreat and return to their territories or rejoin conspecifics nearby; however, in some instances the behaviour escalates and the animals attack the predator, harassing or mobbing it. ${ }^{1}$ A small bird, or more often a group of birds, mobbing a Red-tailed Hawk (Buteo jamaicensis) or a Great Horned Owl (Bubo virginianus) is a common sight, but few people have witnessed, and photographed, mobbing or harassment of Great Gray Owls (Strix nebulosa). Herein I describe, with a series of photographs, mobbing of a pair of Great Gray Owls at a nest in the Spruce Siding area of southeastern Manitoba. I also report an additional observation of mobbing at this nest on an earlier visit and two episodes of mobbing at another gray owl nest in Minnesota, all in 1974. These observations, albeit anecdotal and involving only five episodes of this behaviour at two gray owl nests, add to the growing body of observations of the interactions between nesting Great Gray Owls and other species, including potential predators and nest competitors. ${ }^{2}$ Counterattacks have been recorded occasionally during episodes of predator mobbing, sometimes with deadly results, revealing that under some circumstances mobbing is dangerous. ${ }^{3,4}$ It is, therefore, important to determine the outcomes of these events, whenever possible.

\section{The Nests and Observations}

Efforts to observe Great Gray Owl nests near the U.S.-Canadian border, north of Roseau, Minnesota, were prompted by the discovery and an extensive photographic study of a nest by Robert W. Nero, Dalton Muir and Robert R. Taylor, in $1970.5,6,7$ The collapse of this nest later in the season prompted Nero and others to erect two artificial nests nearby, one in 1970 that was visited by a gray owl in late winter 1971 but the nest was not occupied that year, or in 1972 or 1973. The second artificial nest was built in winter 1973 and was occupied weeks later by a pair of hawks, possibly Red-tailed Hawks and by a pair of Red-tailed Hawks in $1974 .^{7}$ The first artificial nest was finally used by gray owls in 1974 and two eggs were laid (Figure 1). Two observations of mobbing were made at this nest on 25 May.

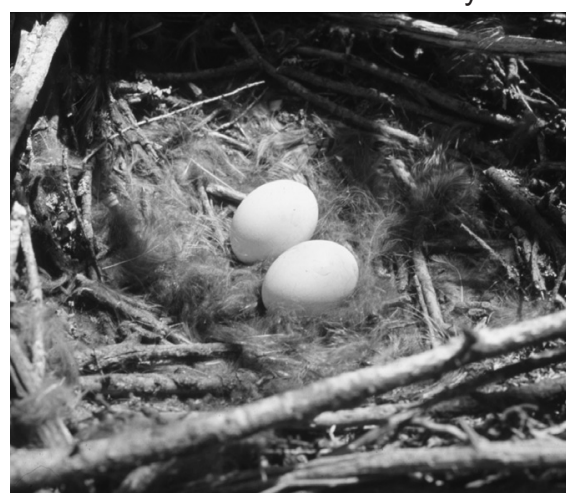

Figure 1. Great Gray Owl clutch in artificial nest, north of Roseau, MN, 25 May 1974.

During a brief visit on 25 May 1974, the female owl, which was perched 
conspicuously several meters to one side of the nest, was mobbed for nearly six minutes simultaneously by two adult Gray Jays (Perisoreus canadensis) before they abruptly left the area. This was followed less than one minute later by a single pass by a Red-tailed Hawk, uttering the familiar hoarse scream, keeeee-arrr. ${ }^{8}$ In each case, the mobbing birds retreated and were not seen during the remaining few minutes that I was at the nest site. The male owl was not seen.

The discovery of the nest near Spruce Siding, in 1973, by Robert W. Nero and Robert R. Taylor, was described eloquently a few years later in Nero's book The Great Gray Owl: phantom of the northern forest. ${ }^{9}$ The initial search for the nest was prompted by a sighting of a Great Gray Owl crossing a road carrying a vole in its bill, a telltale sign that a male owl was on its way to a nest with food to be passed to an incubating or brooding female. The nest was in a deformed tamarack surrounded by dense cover in a spruce-tamarack bog (Figure 2), and contained a single owlet. This nest was used again in 1974, quite possibly by one or both owls that used the nest the previous year. ${ }^{2}$ I visited the nest four times in 1974, on 17 May and 8 June, when the observations of mobbing behavior were made, and with Nero on a date in late May and on 2 June. The nest contained three eggs on my first visit, 17 May, but by late May Nero and I recorded two newly hatched young and one unhatched egg. By 2 June a dead one-day-old chick lay under the nest and the two slightly older chicks remained in the nest. The nest contained two owlets when I visited it again on 8 June but when Nero visited the site again several days later in the month, the skimpy nest had collapsed and neither the adults nor the owlets were seen again. ${ }^{9}$ The nest was "rebuilt" by Nero on the same branch and reinforced by a wire basket. ${ }^{10}$

On 17 May 1974, as I started to climb down from the nest, the female owl, which

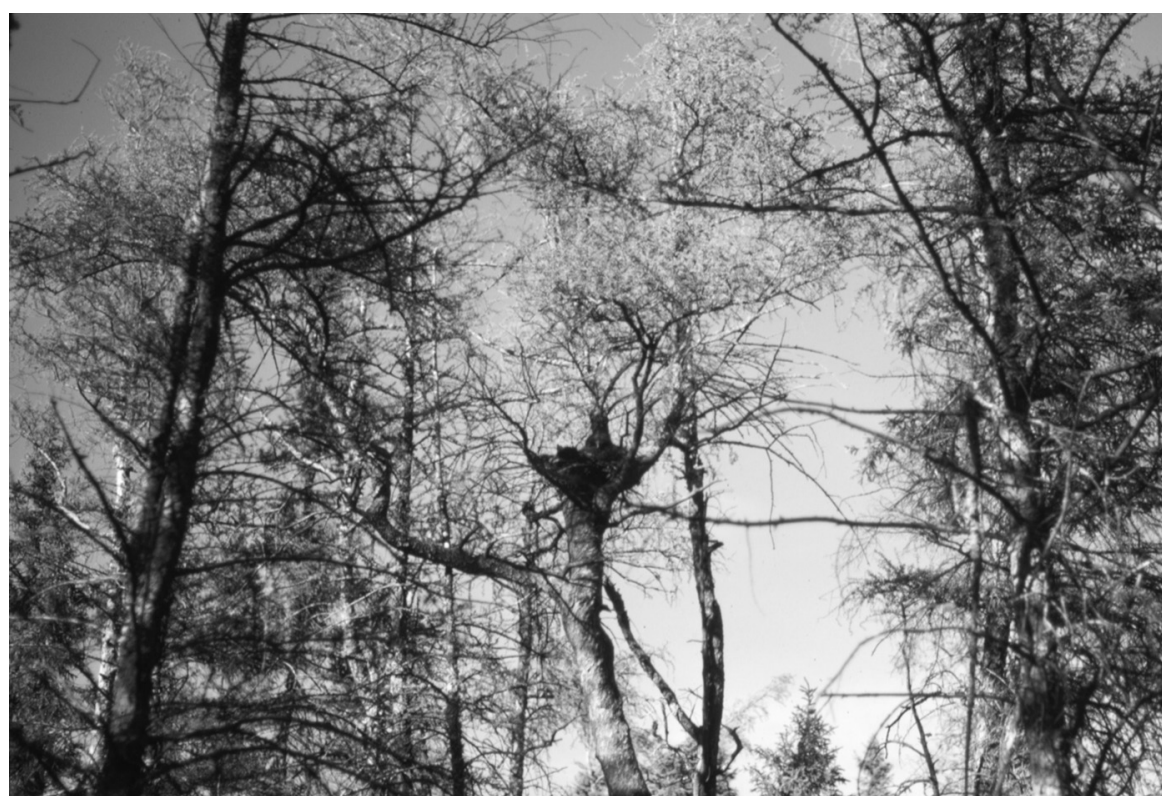

Figure 2. Great Gray Owl nest in a spruce-tamarack bog near Spruce Siding, MB, 8 June 1974. 
was perched on a dead branch about 8 $\mathrm{m}$ high and just off to the side of the nest was attacked seven times by a screaming Broad-winged Hawk (B. platypterus), each pass missing the owl by less than $1 \mathrm{~m}$. The female followed the hawk with its eyes during each pass, slightly ruffled her plumage in a defensive attitude, and shifted her position on the branch a couple of times until the hawk left abruptly. The male owl was neither seen nor heard during this episode. On 8 June, at the same nest, I observed, initially, a male gray owl, which was perched about $30 \mathrm{~m}$ from its nest, being watched from above by an adult Gray Jay. As I approached the male owl on my way to the nest, the jay flew in and perched about $1.5 \mathrm{~m}$ above the male owl and remained there for at least three minutes without attacking the owl. The owl looked up from its perch at the jay continuously during this time but neither the jay nor the owl moved nor uttered vocalizations that I could hear

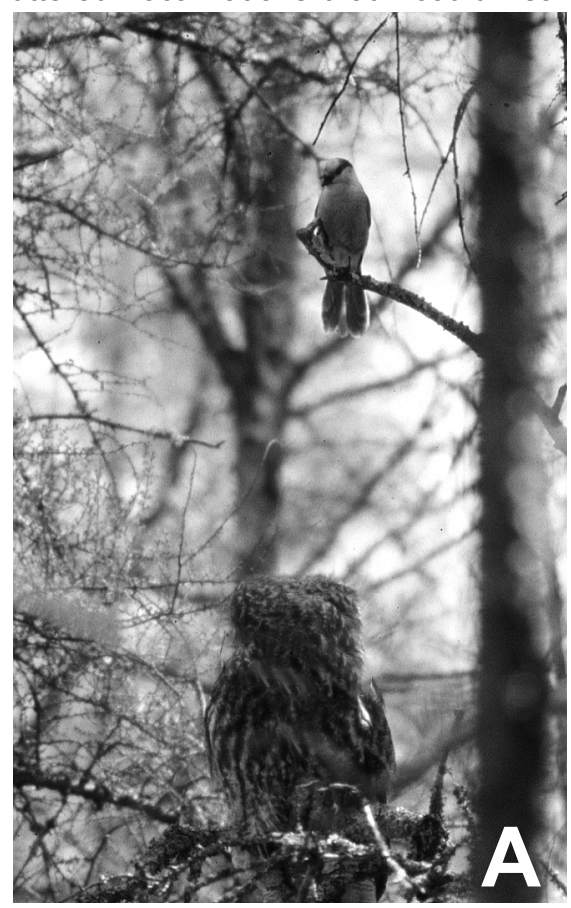

(Figure $3 \mathrm{~A}$ and $3 \mathrm{~B}$ ). When I eventually approached the nest site, the female owl flushed and perched at about the same height on the same branch from which she was mobbed by the Broad-winged Hawk on my previous visit, and peered fixedly at me. She then moved to a branch near the top of a dead spruce above the nest and, minutes later, the female abruptly turned toward a Red-tailed Hawk as it attacked her (had she heard it coming?), almost forcing her to lose her footing each of the five times the hawk attacked the owl (Figure 4A-C). The owl changed perches but remained similarly conspicuous at the top of a live spruce above the nest. The hawk retreated and was not seen again; however, within a few minutes an adult Gray Jay began to mob the owl (Figure 4D - F). As far as I could determine, neither the jay(s) nor the hawk struck either of the owls, but they came close, and the passes by the hawk elicited defensive responses by the female owl (Figure 4).

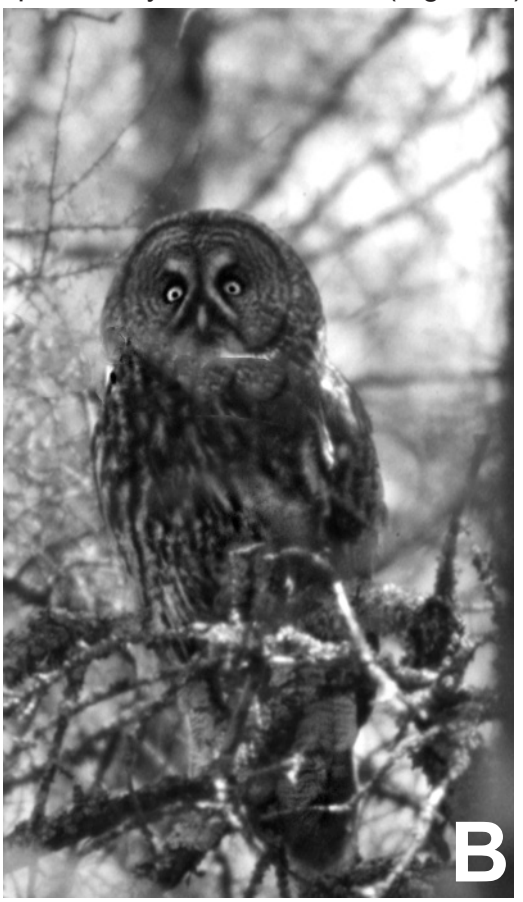

Figure 3. Male Great Gray Owl peering up at a Gray Jay perched motionless about $1.5 \mathrm{~m}$ above it, near Spruce Siding, Manitoba, 8 June 1974.

70 (2) June 2012 

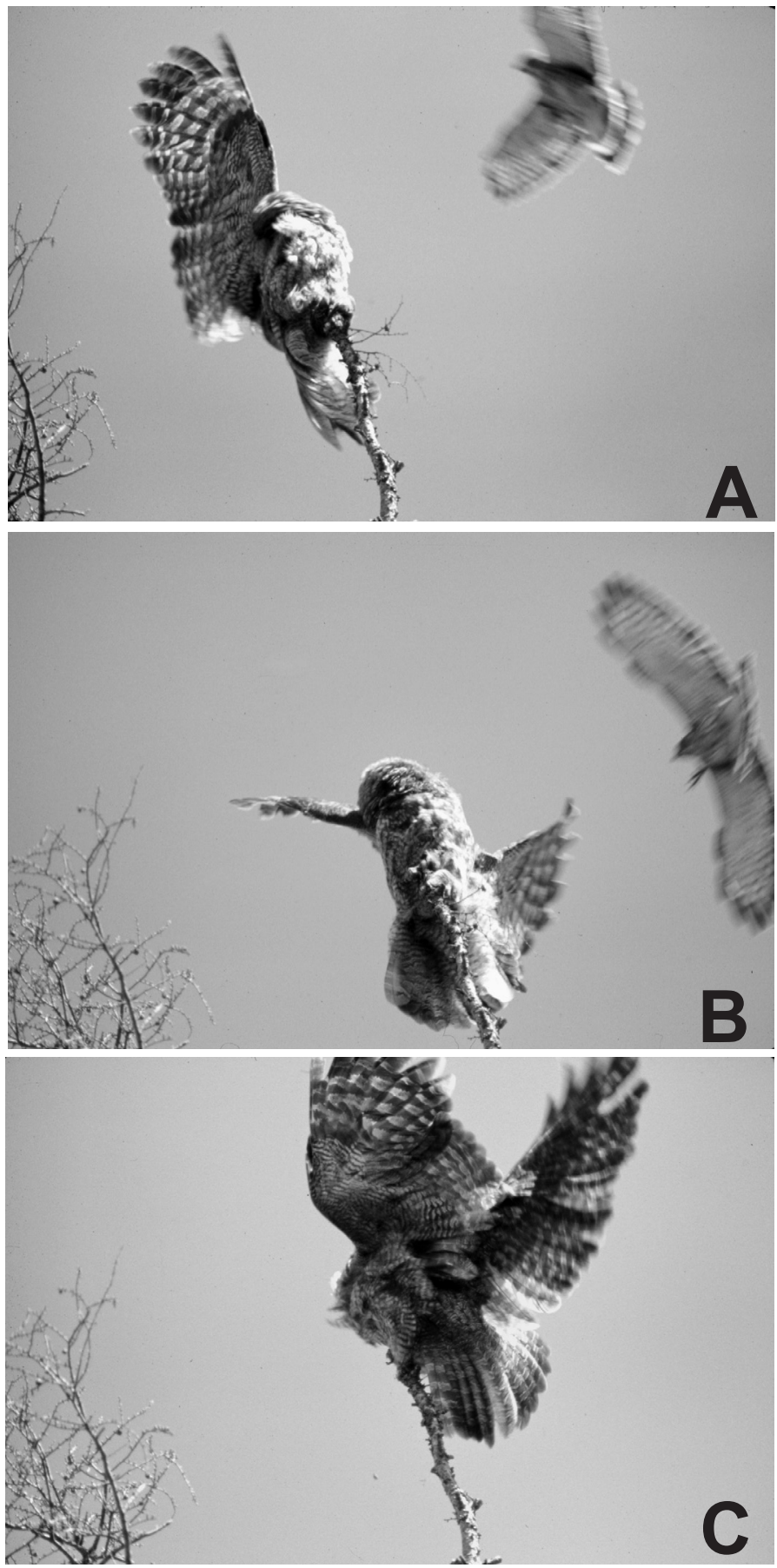

Figure 4. Female Great Gray Owl being mobbed by a Red-tailed Hawk (A-C) and a Gray Jay (D-F), near Spruce Siding, Manitoba, 8 June 1974 

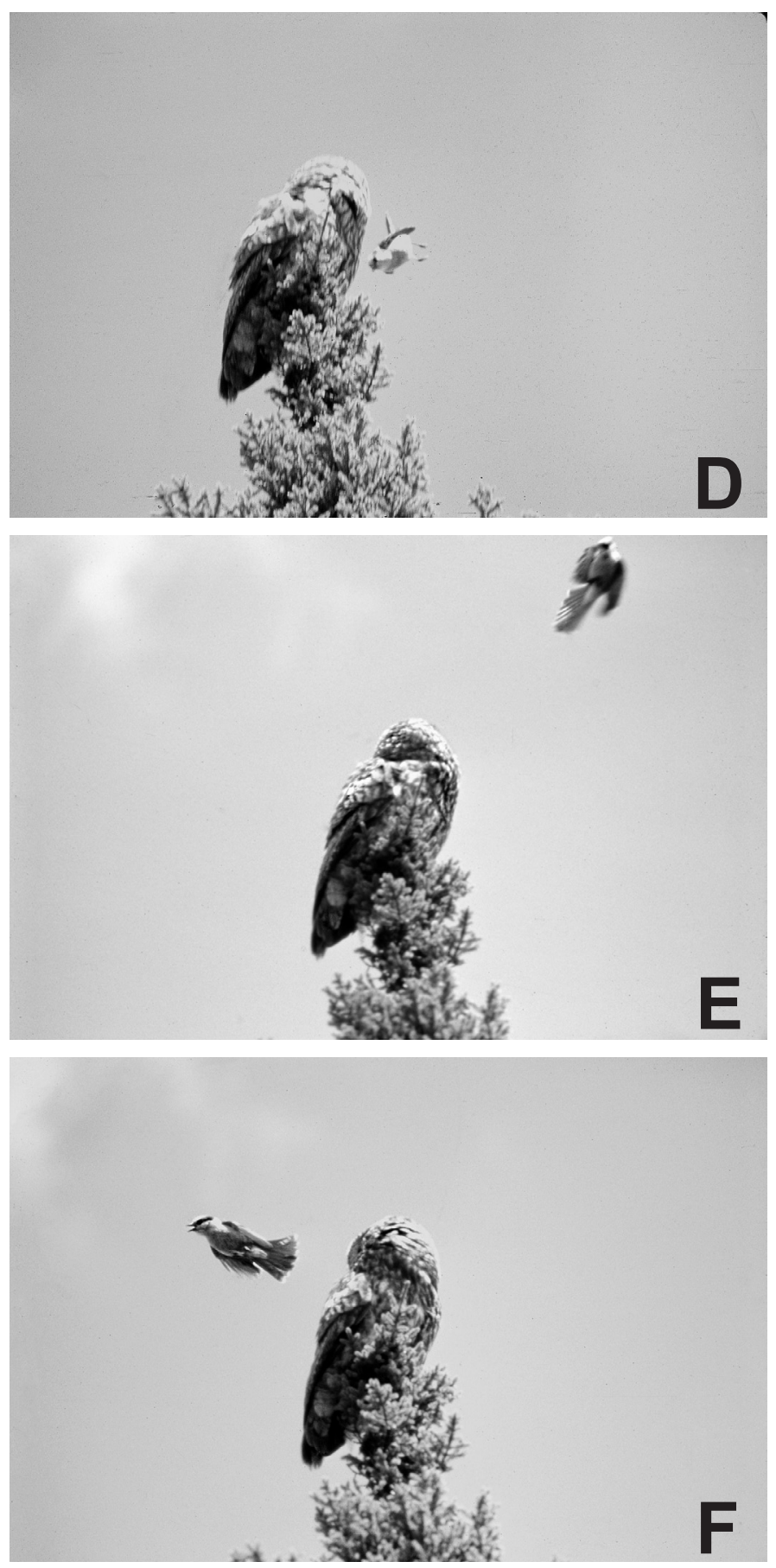
The owl seemed to follow the jay with its eyes as it passed by but it did not shift its position, as it had when the hawk attacked. Neither the male nor the female owl motioned toward or counter-attacked the hawk or the jay, and they did not retreat to denser cover. The male owl was not seen while the female was mobbed and its occasional hoots originating from nearby did not elicit vocal responses from its mate.

\section{Observations by Other Naturalists}

Other naturalists have observed Great Gray Owls in the Prairie Provinces infrequently being attacked or investigated by apparently curious birds. Oeming observed a Great Gray Owl in Alberta reacting to a single pass by a Red-tailed Hawk by "... immediately assum[ing] a defensive attitude, hunching the shoulders and fluffing out the feathers .... She made no attempt to fly at the hawk, which in turn made no further assaults." ${ }^{11}$ One of the first naturalists to record observations of the behaviour of the Great Gray Owl in Saskatchewan, near Choiceland, was Law $^{12}$, who stated:

... [o]n several occasions I have seen chickadees and juncos in the same tree only a few feet away from the [Great Gray] owl but making no commotion. They merely seemed curious about the owl. The owl, for its part, didn't pay the slightest attention to these small birds. I have also seen Blue Jays [Cyanocitta cristatus] in the same tree which showed no signs of fear of the owl, and the owl made no move to attack them. ... these owls have few enemies. I have seen a Goshawk [Accipiter gentilis] on several occasions making dives at one, but the owl merely ruffled its feathers and ducked its head, until the Goshawk moved on.
Despite observing many Great Gray Owls during a large influx of individuals into Manitoba during the winter and spring of 1968-69, Nero infrequently recorded interactions between Great Gray Owls and other species. ${ }^{13}$ He noted:

Our observations of contacts between Great Gray Owls and other species of birds are limited but similar to reports by others ..., there being nothing to indicate that birds regard this species as an enemy. On a few occasions a Common Raven [Corvus corax] made a casual pass at a perched owl and once a Gray Jay flew in briefly. The owls were otherwise ignored though there were lots of opportunities for Black-capped [Poecile attricapilla] and Boreal [P. hudsonicus] chickadees, Gray and Blue jays and other species, to come in contact with them.

Even newly fledged Great Gray Owls (Figure 5) are not immune to attacks by other birds. Nero described (p. 122) an incident near the Roseau nest in 1970 “... one youngster being harassed by several birds, a mob scene involving a Northern Flicker [Colaptes auratus], Blue Jay, Gray Jay, and several Black-capped Chickadees. The owl flew off clumsily when [Nero] approached, flapping away with legs dangling, and made an awkward landing on a branch." 9 Nero's observation of the fledgling owl being mobbed by several species attacking or investigating the owl simultaneously, which is more typical of what is usually considered as mobbing. None of the attacks on the adult Great Gray Owls that I described attracted other individuals, of the same or other species, to the scene.

\section{Discussion}

The behaviour of the hawks and jays I describe suggests that these species were nesting in the area or, in the 


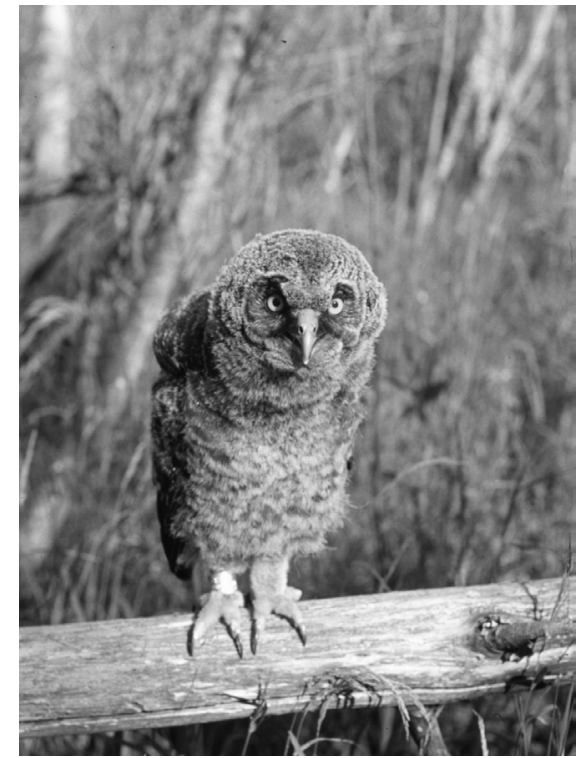

Figure 5. One of two Great Gray Owls fledged from a nest near Lac du Bonnet, Manitoba, July 1974.

case of the earlier-nesting Gray Jays, possibly were attending fledged young; however, nesting by either species was not confirmed near the Spruce Siding nest. The Red-tailed Hawk that attacked the female owl near the nest in Minnesota was likely one of a pair that was nesting nearby, but this could not be confirmed. Individuals are known to mob putative predators outside the breeding season but the number of birds involved and the duration of mobbing generally wanes over the weeks following the breeding season. ${ }^{14}$ The Gray Jays likely perceived the male and female Great Gray Owls as threats, despite the fact that Great Gray Owls rarely take birds, although the Gray Jay is among the few species of birds that have been recorded in the Great Gray Owl's diet. ${ }^{2}$ The jays may have mobbed the Great Gray Owl simply because they recognized it as a large owl, "... or [as] a stimulus resembling [it]" ${ }^{14}$ because the potentially more dangerous Great Horned Owl also occurred in the same general area. The jay was the first and apparently only bird to react to the presence of the male owl, which, unlike the female owl, was perched under a dense canopy (Figure 2), where it may have been less accessible to aerial attacks from above. The (other?) jay may have reacted to the attacks on the female owl by the Redtailed Hawk and followed suit, mobbing the owl only after the hawk left the area. This explanation seems unlikely, however, because the jays were the first to mob the owl at the Roseau nest, followed by the Red-tailed Hawk.

The motive for mobbing the Great Gray Owl by the apparently more powerful Redtailed Hawk, and possibly Broad-winged Hawk, is not readily evident, although the Red-tailed Hawk has been recorded depredating young Great Gray Owls. ${ }^{15}$ Great Gray Owls use broken-topped snags and old nests built by other species in previous years, primarily by hawks and, occasionally use mistle-toe brooms; hence, there may be an unappreciated competition for these nests, as hawks will use old nests again in subsequent years. Observations are numerous of Broad-winged and Red-tailed hawks, and other species, attacking other species of hawk, within and outside of the breeding season, and in some cases apparently pirating their food or killing them, and also counter-attacking. ${ }^{16,17,18,19,20,21,22}$

The behavioural interactions that I described may have been somewhat artificial because the jays and hawks may have responded initially to my presence near and at the owls' nests, and then focused their attacks on the female owls when they perched conspicuously above and beside their nests. My observations, however, suggest that the hawks' attention was directed solely toward the owls because they did not appear and react to me as I walked through the bog toward the owls' nests, as I would 
have expected if they were responding to my presence. Instead, the hawks immediately directed their attention toward the owls, almost as soon as they perched conspicuously after I arrived at the nest sites. None of the hawks lingered after they stopped mobbing the owl, even though I remained at the nest sites for several minutes. Martin McNicholl (pers. comm.) suggested that if the hawks and/ or jays were nesting near the owls, they may have habituated to the owls' proximity and did not attack them if they remained out of sight most of the time, then they attacked when the owls suddenly became conspicuous, as in their response to me. He documented habituation of aggressive responses by nesting terns (Sterna spp.) toward potential avian predators that nested within or alongside the colonies. ${ }^{23}$ Undisturbed Great Gray Owls are fairly inconspicuous around the nest, depending on the density of the habitat and the nest's exposure (Nero 1980); however, male Great Gray Owls also hunt during the day, thus attracting attention, especially when the owls are carrying prey to the nest; this may provide opportunities for food piracy. Long-term video-monitoring of Great Gray Owl nests, may provide a more unbiased description of the frequency of interactions between the owls and other species encountered at their nests.

\section{Acknowledgements}

I am indebted to Bob Nero and Herbert W.R. Copland for the pleasure of accompanying them on their far-reaching travels throughout southeastern Manitoba and northern Minnesota in search of Great Gray Owls and their nests. One does not soon forget the sight of a Great Gray Owl perched atop a pole or on the tip of a spindly tamarack at the forest's edge as it scans a field listening for telltale signs of a vole under the snow, seemingly oblivious to the humans watching it from a nearby road. I thank
Martin K. McNicholl, R. Wayne Nelson and Robert W. Nero for providing thoughtprovoking comments on the manuscript and suggesting additional references.

1. Dugatin LA (2004) Principles of Animal Behavior. W.W. Norton, New York, NY.

2. Bull EL, Duncan JR (1993) Great Gray Owl (Strix nebulosa), no. 41 in The Birds of North America (Poole A, Gill, F, editors). Philadelphia: The Academy of Natural Sciences; Washington, D.C.: The American Ornithologists' Union.

3. Hennessy DF (1986) On the deadly risk of predator harassment. Ethology 72:72-74.

4. Sordahl TA (1990) The risks of avian mobbing and distraction display: an anecdotal review. Wilson Bulletin 102:349-352.

5. Nero RW (1970) Great Gray Owls nesting near Roseau. Loon 42:88-93.

6. Muir D (1972) At a nest of the Great Gray Owl. Nature Canada 1(2):20-22.

7. Nero RW, Sealy SG, Copland HWR (1974) Gray Gray Owls occupy artificial nest. Loon 46:161-165.

8. Preston CR, Beane RD (1993) Redtailed Hawk (Buteo jamaicensis), no. 52 in The Birds of North America (Poole A, Gill, F, editors). Philadelphia: The Academy of Natural Sciences; Washington, D.C.: The American Ornithologists' Union.

9. Nero RW (1980) The Great Gray Owl: phantom of the northern forest. Smithsonian Institution Press, Washington, D.C.

10. Nero RW (1982) Building nests for Great Gray Owls. Sialia 4:43-48. 
11. Oeming AF (1955) A preliminary study of the Great Gray Owl (Scotiaptix nebulosa nebulosa) (Forster) in Alberta with observations on some other species of owls. M.Sc. thesis, University of Alberta, Edmonton, AB.

12. Law C (1960) The Great Gray Owl of the woodlands. Blue Jay 18:14-16.

13. Nero RW (1969) The status of the Great Gray Owl in Manitoba, with special reference to the 1968-69 influx. Blue Jay 27:191-209.

14. Altmann SA (1956) Avian mobbing behavior and predator recognition. Condor 58:241-249.

15. Bull EL, Henjum MG (1990) Ecology of the Great Gray Owl. United States Department of Agriculture, Forest Service, General Technical Report, PNW-GTR-265.

16. Broun M (1947) Golden Eagle captures Red-shouldered Hawk. Auk 64:317-318.
17. Collins CT (1962) Red-tailed Hawk attacks Long-eared Owl. Wilson Bulletin 74:89.

18. Weigand JP (1967) Ferruginous Hawk attacks Great Horned Owl. Auk 84:433.

19. Clark RJ (1971) Red-tailed Hawk attempts piracy of Sparrow Hawk? Kingbird 21:10.

20. Todd DM (1980) Golden Eagle killing Buzzard. British Birds 73:536-537.

21. Nero RW (1994) Short-tailed shrew apparently cause of mortality of Eastern Screech-Owl. Blue Jay 52:176-178.

22. Gibson MJ, Gibson DC, Bardelmeier DG (1998) Prey conquers predator: a case study. Journal of Wildlife Rehabilitation 21:19-21.

23. McNicholl MK (1973) Habituation of aggressive response to avian predators by terns. Auk 90:902-904.

\section{MAMMALS}

\section{WEASELS; NOT ALWAYS PUSHOVER PREY FOR RAPTORS}

WILLIAM J. WALLEY, 222 Bossons Ave., Dauphin, Manitoba, R7N OR2

Known avian predators of weasels (Mustela sp.) include: northern goshawk, red-tailed and rough-legged hawks; northern barred, great horned and snowy owls. ${ }^{1,2,3,4,5,6,7,8,9}$ Banfield excluded mustelids as prey of raptors. 10 On occasion weasel remains link these mustelids to unusual predators such as the discovery at Hamilton Bay, Ontario where a bald eagle (Haliaeetus leucocephalus) that had been shot, had a "bleached skull of a weasel hanging firmly fastened by the teeth into the skin of its throat, a gruesome relic of a former desperate struggle" reported by Thomas Mcllwraith to A.C. Bent. ${ }^{1}$ In 1980 the author discovered the skull of a shorttailed weasel (Mustela erminea) in the cast pellet of a short-eared owl (Asio flammeus) near Dauphin, Manitoba, the only reported such record for this owl species for the entire holarctic. ${ }^{11}$ No 